\title{
APPLICATION OF AHP METHOD FOR THE SELECTION OF PHARMACEUTICAL WAREHOUSE LOCATION
}

\author{
ECZA DEPOSU YERİ SEÇIMINDE AHS YÖNTEMININ UYGULANMASI
}

\begin{abstract}
Miray ARSLAN*
Van Yüzüncü Y1l Üniversitesi, Eczacılık Fakültesi, Eczacılık İşletmeciliği Anabilim Dalı, 65080, Van, Türkiye
\end{abstract}

\begin{abstract}
Objective: The primary purpose of this study is to find a solution to the warehouse location selection problem of a pharmaceutical warehouse serving in the pharmaceutical industry by using the Analytical Hierarchy Process (AHP) method.

Material and Method: Within the scope of this study, a possible new warehouse location problem that can be established in the Eastern and Southeastern Anatolia Region of Turkey for a pharmaceutical warehouse, which has a significant market share among the drug distribution channels in Turkey, will be solved with the AHP method. Firstly, the algorithm for the AHP is determined. Then, pair-wise comparison matrices for determined criteria and alternatives were prepared by decision-makers, and matrices were transferred to the Super Decision package program for the solution.

Result and Discussion: As a result, the most important criterion in the selection of the pharmaceutical warehouse location was determined as the infrastructure and physical conditions (35\%) and transportation conditions (29\%) followed by it. According to these criteria, the first alternative was found as the optimum.

Keywords: analytical hierarchy process, pharmaceutical warehouse, location selection

\section{$\ddot{\mathbf{O Z Z}}$}

Amaç: Bu çalışmanın temel amacı, eczacılık sektöründe hizmet sunmakta olan bir ecza deposunun ecza deposu yeri seçim problemine Analitik Hiyerarşi Süreci (AHS) yöntemi ile çözüm bulmaktır.

Gereç ve Yöntem: Bu çalışma kapsamında, Türkiye’de ilaç dă̆ıtım kanalları arasında önemli bir Pazar payına sahip olan bir ecza deposunun Türkiye'de Doğu ve Güneydoğu Anadolu Bölgesinde kurulabilecek olası bir yeni deposu yer seçimi problemi AHS yöntemi ile çözülmüştür. İlk olarak, AHS algoritması belirlenmiştir Ardından belirlenen kriterler ve alternatifler için karar vericiler tarafindan ikili karşılaştırma matrisleri oluşturulmuş ve çözüm için matrisler Super Decision programına aktarılmıştır.

Sonuç ve Tartışma: Sonuç olarak, ecza deposu yer seçiminde en önemli kriter altyapı ve fiziksel koşullar (\%35) kriteri olmuştur, bunu ulaşım koşulları (\%29) takip etmiştir. Bu kriterler doğrultusunda en iyi depo yeri birinci alternatif olarak bulunmuştur.

Anahtar Kelimeler: analitik hiyerarşi süreci, ecza deposu, yer seçimi
\end{abstract}

\footnotetext{
* Corresponding Author/Sorumlu Yazar: Miray Arslan e-mail / e-posta: eczmirayarslan@gmail.com, Phone / Tel.: +90 4324445065 / 21148
} 


\section{INTRODUCTION}

Today, according to the increase in the importance of globalization, supply chain management must be done correctly in order to ensure the continuity of the businesses. Logistics processes play a crucial role in continuing the supply chain without interruption, and warehouse management is among the critical activities of logistics [1]. Warehouse location selection, as one of the main functions of warehouse management, is a strategic decision-making process that has long term effects such as improving service quality, making economic progress, preventing material losses and, environmental problems. In this context, the choice of warehouse location, which is one of the critical decisions affecting the speed, profitability, and efficiency of the enterprises, is significant in terms of both cost and time $[2,3]$.

In Turkey, pharmaceutical warehouses are one of the crucial members of the pharmaceutical supply chain by providing purchasing, selling, and distribution of pharmaceutical products in frame of current legal conditions [4]. Services offered by pharmaceutical warehouses directly affect the services provided both in pharmaceutical companies as suppliers and in pharmacies where distribution is provided to consumers. Warehouse activities should be carried out correctly in order to avoid problems such as delays in the process of taking a drug from the pharmaceutical company and delivering it to the patient through community pharmacies. The location of the warehouse is critical in the distribution process, which is one of these activities. In this study, an application was made for the selection of a pharmaceutical warehouse location at the pharmaceutical warehouse that has a significant market share.

The choice of warehouse location should be made with an integrated approach that should be handled together by many factors such as infrastructure, accessibility, legal status, market size, and access to the human resources [2,5]. In other words, the selection of warehouse location is a multivariate decision-making problem that deals with qualitative and quantitative criteria [6]. Multivariate decision-making techniques are frequently used in solving these types of selection problems. The analytical hierarchy process (AHP) is one of these techniques which is commonly preferred in the literature on warehouse location selection [3, 7-10]. Also, many studies apply AHP in the different areas of the pharmaceutical industry [11-14]. For example, Oey and Nitihardjo investigated the problem of location for a pharmaceutical company's regional postponement center via AHP [15]. Enyinda used the AHP model for the selection of suppliers in the pharmaceutical sector [16].

The motivation of this study comes from the lack of studies done with the AHP method related to pharmaceutical warehouses. To the best of author's knowledge, this is the first study that used AHP for solving the pharmaceutical warehouse location selection problem in Turkey. In this context, the 
primary purpose of this study is to find a solution to the warehouse location selection problem of a pharmaceutical warehouse serving in the pharmaceutical industry by using the AHP method. The subobjectives of the study are (i) establishing a hierarchical structure regarding the warehouse location selection problem, (ii) determining the importance (priority) values of the criteria in the hierarchical structure established and, (iii) comparing the warehouse location alternatives in terms of the determined criteria.

\section{MATERIAL AND METHOD}

Within the scope of this study, a possible new warehouse location problem that can be established in the Eastern and Southeastern Anatolia Region of Turkey for a pharmaceutical warehouse, which has a significant market share among the drug distribution channels in Turkey, will be solved with the AHP method. In this section, firstly, general information about the AHP method will be given, then the application process will be discussed in detail.

\section{Analytical hierarchy process}

The decision-making process has a complex structure that includes external factors such as natural phenomena as well as measurable factors. The decision-making process, which involves providing maximum benefits from the alternatives at minimum cost by considering all factors to reach a specific goal, is of great importance for the health sector, as in many different sectors [17].

AHP is one of the multi-criteria decision-making (MCDP) techniques based on pair-wise comparisons, developed by Thomas L. Saaty in the 1970s. This method has a more straightforward structure compared to other MCDP techniques. A multi-dimensional problem is reduced to one dimension by determining the importance (priority) levels of the criteria for the selection of the best alternative in AHP [18].

In the literature, the implementation steps of AHP are summarized as follows [19-22]: The first step of the AHP is to identify the problem. Following the determination of the problem, the hierarchical structure known as modeling, which allows the problem to be divided into various levels, is determined. There are criteria in the lower step of the hierarchy, where the ultimate goal of the problem is at the top and alternatives in the last step. After that, the relative importance matrices of each criterion are calculated. For this purpose, binary comparisons are made. In order to make binary comparisons, the comparison scales accepted in the literature are used. The most preferred one is the importance (priority) scale of Saaty, developed by Thomas Saaty (Table 1). 
Table 1. The importance scale of Saaty [19]

\begin{tabular}{|l|l|}
\hline Importance level & Definition \\
\hline 1 & Equal importance \\
\hline 3 & Moderately more important than one another \\
\hline 5 & Strong importance \\
\hline 7 & Very strong importance \\
\hline 9 & Extreme importance \\
\hline $2,4,6,8$ & Intermediate / average values \\
\hline
\end{tabular}

After calculating the relative significance, the consistency (CR) of the comparison matrices is calculated to determine whether decision-makers are consistent when making binary comparisons. This value is expected to be below 0.1, and matrix consistency increases as it approaches zero. At the last stage, the decision alternatives are listed by creating a composite relative importance matrix. (For detailed information on the manual resolution of AHP, please see 19, 23). Modeling and solution of AHP can be done either manually or with the help of MS Excel or package programs such as "Expert Choice" and "Super Decision" [18]. In this study, AHS was modeled and solved via the "Super Decision" package program.

\section{Application}

The flow diagram followed in the application phase of this study is presented in Figure 1.

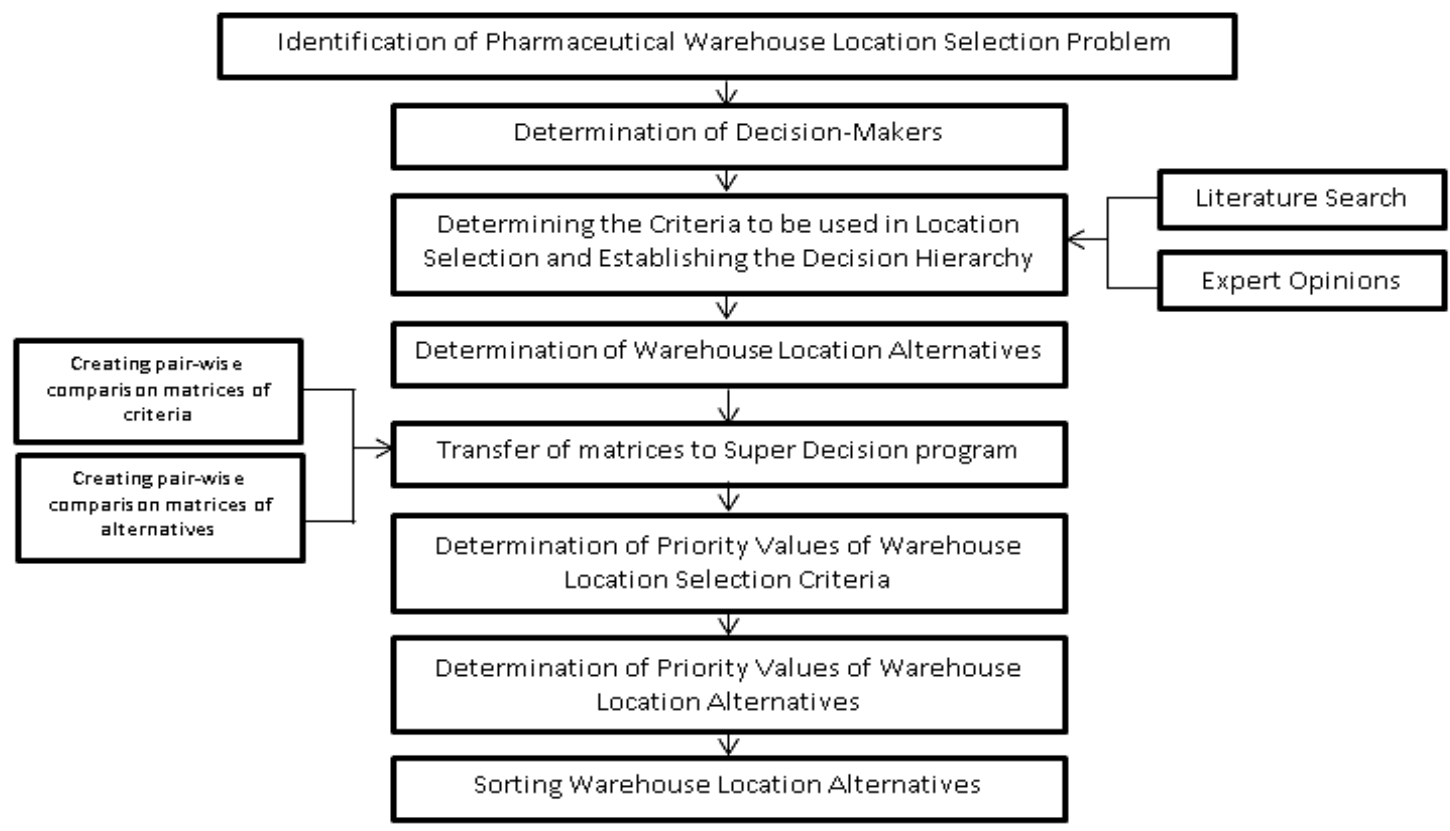

Figure 1. The flow diagram of the application

In line with the flow diagram presented in Figure 1, the decision problem of the study has been defined as; selecting a possible new warehouse location to be established in the Eastern Anatolia 
Region for the XYZ pharmaceutical warehouse (the business name was not given due to confidentiality). Optimizing the level of service quality and minimizing costs are aimed at the solution of the problem.

Three authorities from the firm, related to supply chain management, are selected as the decision-makers of the problem. Following this, appropriate criteria and alternatives warehouse locations are determined according to relevant literature and opinions of the decision-makers. The criteria are determined as; (i) competitors, (ii) costs (rental, labor costs, etc.), (iii) the number of pharmacies and hospitals in the region, (iv) transportation conditions and, (v) infrastructure and physical conditions. Three provinces in the Eastern and Southeastern Anatolia Region of Turkey were identified as alternative locations by the relevant warehouse authorities and coded as; (i) Warehouse1, (ii) Warehouse2 and, (iii) Warehouse3. In this context, the hierarchical structure for the decision problem is presented in Figure 2.

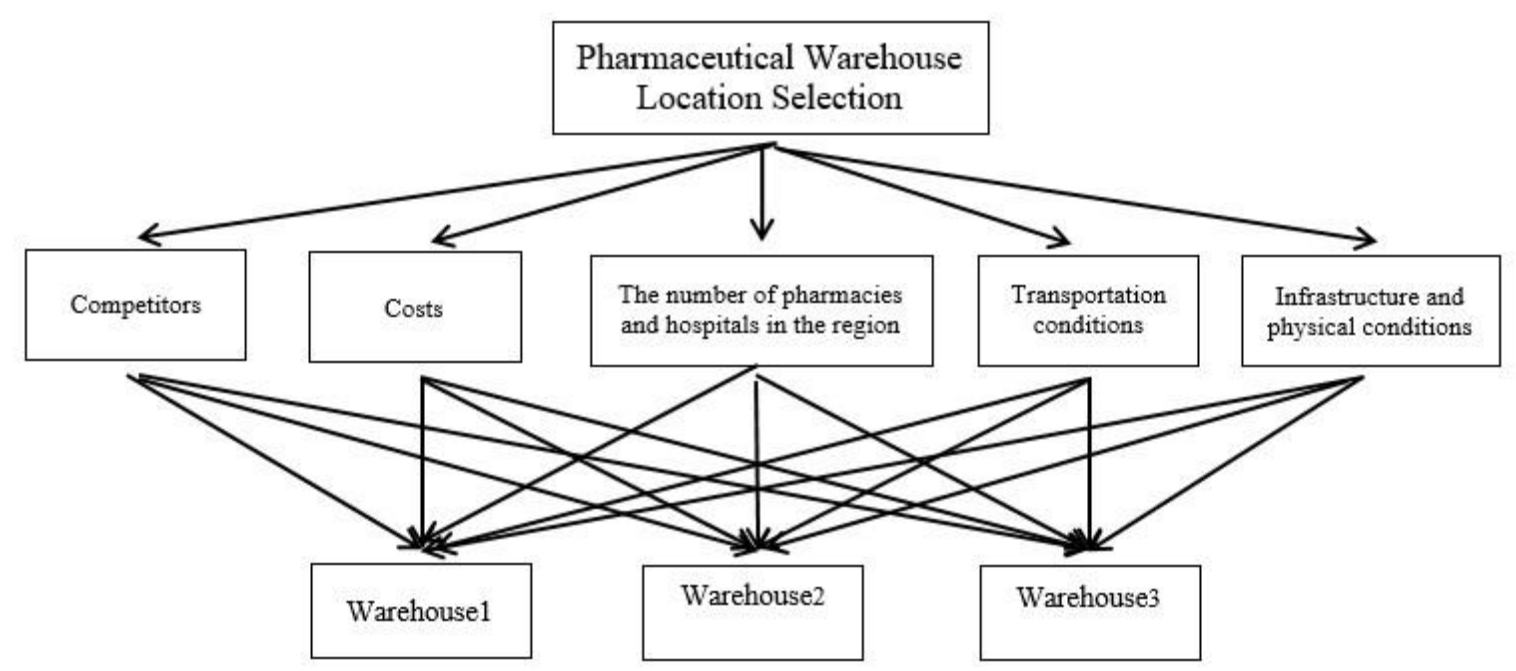

Figure 2. The hierarchical structure of the decision problem

After the hierarchical structure was created, pair-wise comparison matrices for criteria and alternatives were prepared by decision-makers, and matrices were transferred to the Super Decision package program for the solution.

\section{RESULT AND DISCUSSION}

In this section, firstly, geometric averages of pair-wise comparison matrices created by decision-makers are taken. Table 2 presents the findings obtained from the pair-wise comparison matrices for the criteria. 
Table 2. Pair-wise comparison table for criteria

\begin{tabular}{|l|c|c|c|c|l|}
\hline Criteria & $\begin{array}{c}\text { Decision- } \\
\text { maker 1 }\end{array}$ & $\begin{array}{c}\text { Decision- } \\
\text { maker 2 }\end{array}$ & $\begin{array}{c}\text { Decision- } \\
\text { maker 3 }\end{array}$ & $\begin{array}{l}\text { Geometric } \\
\text { averages }\end{array}$ & Criteria \\
\hline Competitors & 5 & 3 & 3 & 3.557 & Costs \\
\hline Competitors & $1 / 5$ & $1 / 3$ & $1 / 5$ & 0.237 & $\begin{array}{l}\text { The number of } \\
\text { pharmacies and } \\
\text { hospitals }\end{array}$ \\
\hline Competitors & $1 / 7$ & $1 / 5$ & $1 / 3$ & 0.212 & $\begin{array}{l}\text { Transportation } \\
\text { conditions }\end{array}$ \\
\hline Competitors & $1 / 5$ & $1 / 5$ & $1 / 7$ & 0.179 & $\begin{array}{l}\text { Infrastructure and } \\
\text { physical conditions }\end{array}$ \\
\hline Costs & $1 / 5$ & $1 / 3$ & $1 / 3$ & 0.281 & $\begin{array}{l}\text { The number of } \\
\text { pharmacies and } \\
\text { hospitals }\end{array}$ \\
\hline $\begin{array}{l}\text { Costs } \\
\text { Costs }\end{array}$ & $1 / 3$ & $1 / 3$ & $1 / 3$ & 0.281 & $\begin{array}{l}\text { Transportation } \\
\text { conditions }\end{array}$ \\
\hline $\begin{array}{l}\text { The number of } \\
\text { pharmacies and } \\
\text { hospitals }\end{array}$ & $1 / 3$ & $1 / 3$ & $1 / 3$ & 0.333 & $\begin{array}{l}\text { Infrastructure and } \\
\text { physical conditions }\end{array}$ \\
\hline $\begin{array}{l}\text { The number of } \\
\text { pharmacies and } \\
\text { hospitals }\end{array}$ & 1 & 1 & $1 / 3$ & 0.480 & $\begin{array}{l}\text { Transportation } \\
\text { conditions }\end{array}$ \\
\hline $\begin{array}{l}\text { Transportation } \\
\text { conditions }\end{array}$ & 1 & $1 / 3$ & 1 & 0.693 & $\begin{array}{l}\text { Infrastructure and } \\
\text { physical conditions }\end{array}$ \\
\hline
\end{tabular}

After entering the data in Table 2 into the Super Decision program, the consistency rates were evaluated. As stated in the pair-wise comparison of the criteria was calculated as 0.969 , and the consistency report obtained as a result of the pair-wise comparison of the criteria is given in Figure 3.

Inconsistency Report

\begin{tabular}{|c|c|c|c|c|c|c|c|}
\hline Rank & Row & Col & Current Val & Best Val & Old Inconsist. & New Inconsist. & $\%$ Improvement \\
\hline 1. & 1_Competitors & 2_Costs & 3.557000 & 1.462564 & 0.096935 & 0.020044 & $79.32 \%$ \\
\hline 2. & 2_Costs & 5_Infrastructure an & 3.558719 & 7.419274 & 0.096935 & 0.074695 & $22.94 \%$ \\
\hline 3. & 1_Competitors & 3_The number of $p$ & 4.219409 & 1.533629 & 0.096935 & 0.076354 & $21.23 \%$ \\
\hline 4. & 2_Costs & 4_Transportation c & 3.003003 & 5.916529 & 0.096935 & 0.077911 & $19.63 \%$ \\
\hline 5. & 3_The number of $\mathrm{p}$ & 4_Transportation c & 2.083333 & 1.111281 & 0.096935 & 0.086235 & $11.04 \%$ \\
\hline 6. & 1_Competitors & 4_Transportation c & 4.716981 & 2.612650 & 0.096935 & 0.090781 & $6.35 \%$ \\
\hline 7. & 1_Competitors & 5_Infrastructure an & 5.586592 & 3.255155 & 0.096935 & 0.092577 & $4.50 \%$ \\
\hline 8. & 3_The number of $p$ & 5_Infrastructure an & 2.083333 & 1.544979 & 0.096935 & 0.094656 & $2.35 \%$ \\
\hline 9. & 4_Transportation $\mathrm{c}$ & 5_Infrastructure an & 1.443001 & 1.108613 & 0.096935 & 0.095313 & $1.67 \%$ \\
\hline 10. & 2_Costs & 3_The number of $p$ & 3.558719 & 3.120641 & 0.096935 & 0.097496 & $-0.58 \%$ \\
\hline
\end{tabular}

Figure 3. Screenshot of the consistency report of the pair-wise comparison matrix of criteria

According to Figure 3, no inconsistency was observed in the pair-wise comparisons made by the decision-makers, and priority values for each criterion were calculated. In Figure 4, the priority rankings of the criteria are presented. 


\begin{tabular}{|c|c|c|c|}
\hline \multicolumn{4}{|c|}{ Here are the priorities. } \\
\hline Icon & Name & Normalized by Cluster & $\overline{\text { Limiting }}$ \\
\hline No Icon & $\begin{array}{l}\text { 1_Selection of the best } \\
\text { alternative }\end{array}$ & 0.00000 & 0.000000 \\
\hline No Icon & 1_Competitors & 0.08942 & 0.044711 \\
\hline No lcon & 2_Costs & 0.06279 & 0.031393 \\
\hline No Icon & $\begin{array}{c}\text { 3_The number of } \\
\text { pharmacies and hospitals }\end{array}$ & 0.20505 & 0.102526 \\
\hline No Icon & $\begin{array}{l}\text { 4_Transportation } \\
\text { conditions }\end{array}$ & 0.28923 & 0.144615 \\
\hline No Icon & $\begin{array}{l}\text { 5_Infrastructure and } \\
\text { physical conditions }\end{array}$ & 0.35351 & 0.176755 \\
\hline Okay $\mathrm{C}$ & opy Values & & \\
\hline
\end{tabular}

Figure 4. Priority values of warehouse location selection criteria

By Figure 4, the most important criterion in the selection of the warehouse location was determined as the infrastructure and physical conditions (35\%) covering many subjects from the availability of areas suitable for the acceptance and shipment of goods to the storage to the suitability of cleaning, sewerage conditions and information technologies. These criteria are also highlighted in the legislation for pharmaceutical warehouses in Turkey. According to the "Good Distribution and Storage Practices Guideline for pharmaceuticals and products in warehouses," published by Turkish Medicines and Medical Devices Agency (TMMDA), pharmaceutical warehouses must have adequate and appropriate buildings, areas, equipment and physical structuring. These requirements are fundamental to ensure that products are stored and distributed under appropriate conditions [24]. Parallel to this, Kolinska and Fechner stated similar constraints and emphasized the importance of infrastructure for selection of warehouse location [2,25]. In addition to the infrastructure, the importance of transportation conditions was also demonstrated in these studies. If it is needed to address the issue in pharmaceutical warehouses, the warehouse must be located in an easily accessible location to both suppliers and pharmacies in order to ensure efficient product flow in pharmaceutical warehouses. When the locations of drug distribution channels operating in Turkey are evaluated, it is seen that both central warehouses and auxiliary warehouses are located in places where transportation facilities are comfortable, and land conditions are convenient for transportation. Accordingly, it is not surprising that transportation conditions (29\%) were found to be one of the two most essential warehouse location selection criteria in this study.

As mentioned by Fechner, economic and demographic criteria are both critical for determining warehouse location [25]. Kua and Kao found competition factors, including competitor's store 
numbers, store area, and competition, as the most critical factor for the selection of convenience stores located in the retail sector. They also evaluated the distance for consumer and economic values for competition [26]. Following, they put forth that all of these factors should take into consideration together for the best selection. In the present study, contrary to this, competitors (9\%) and costs (6\%) are found as the least influencing criteria. This situation is thought to arise from the sector difference in which the studies are carried out. Besides, in this study, rental and labor costs are discussed under the cost criterion. Decision-makers stated that the unemployment problem is similar for all three alternatives, so labor costs will not make a difference. Similarly, the idea that the rental prices would be similar caused the costs factor to be the least influential factor in the selection of the pharmaceutical warehouse location.

Following the weighting of the criteria, the pair-wise comparison matrices for alternative warehouse locations were created by the decision-makers for each criterion, and the geometric averages of them were transferred to the Super Decision program. The program output regarding the evaluation of alternative warehouse locations according to the "competitors" criterion is presented in Figure 5.

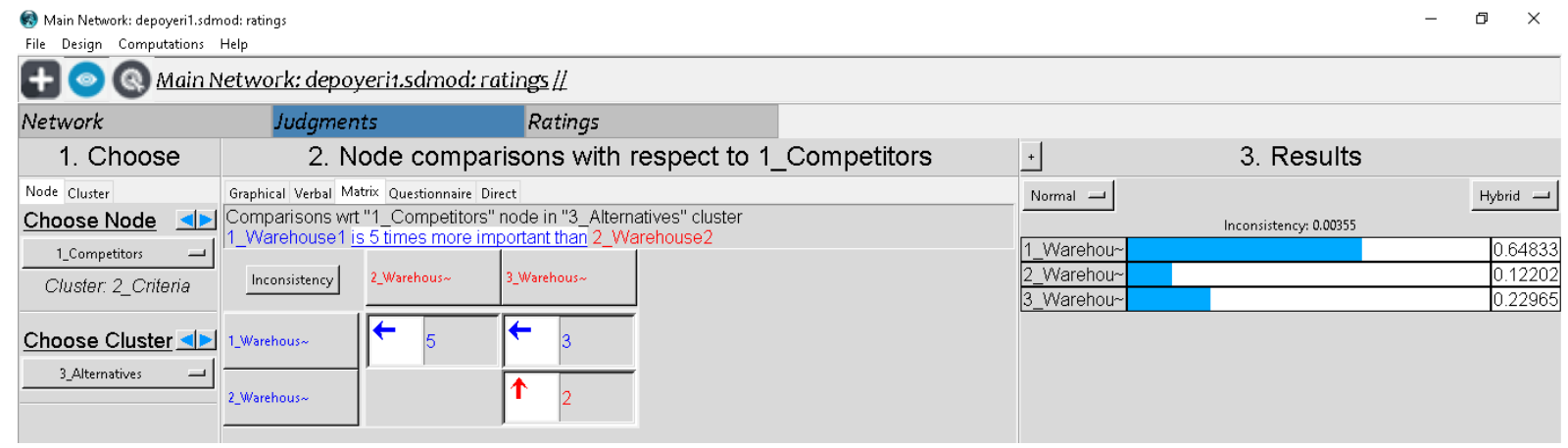

Figure 5. Program output based on the "Competitors" criterion

According to Figure 1, considering the "competitors" criterion, the best alternative is the Warehouse1, with a weight of 0.648 . The consistency rate for this assessment was calculated as 0.0035. The program output obtained as a result of the evaluation of alternative warehouse locations according to the "Costs" criterion is given in Figure 6. 
2. Main Network: depoyeri1.sdmod: ratings

File Design Computations Help

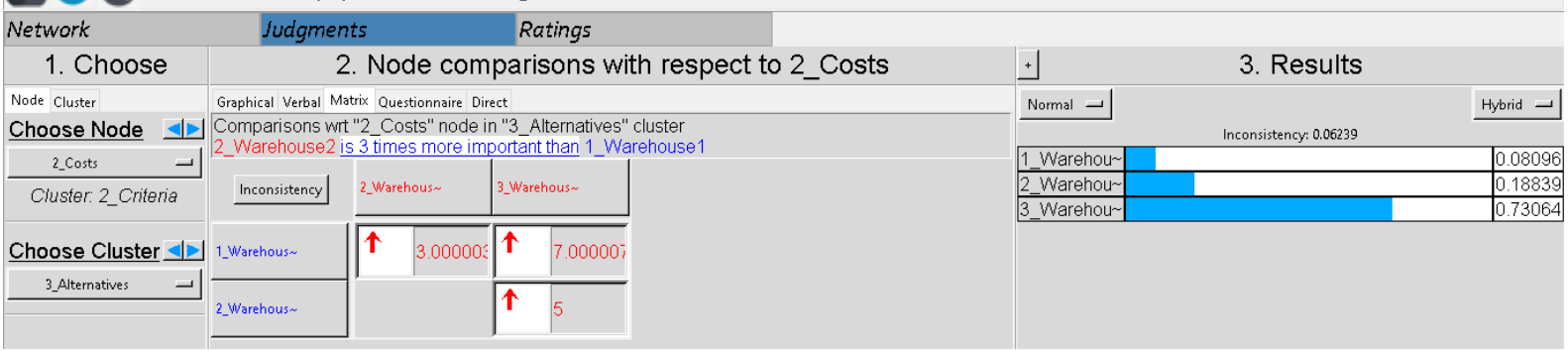

Figure 6. Program output based on the "Costs" criterion

Results in Figure 6 shows that considering the costs, it is determined that the best alternative is Warehouse3, with a weight of 0.730 . The consistency rate for this assessment was calculated as 0.0623. In Figure 7, the program output obtained as a result of the evaluation of alternative warehouse locations under the criterion of "the number of pharmacies and hospitals in the region" is shown.

Main Network: depoyeri1.sdmod: ratings

File Design Computations Help

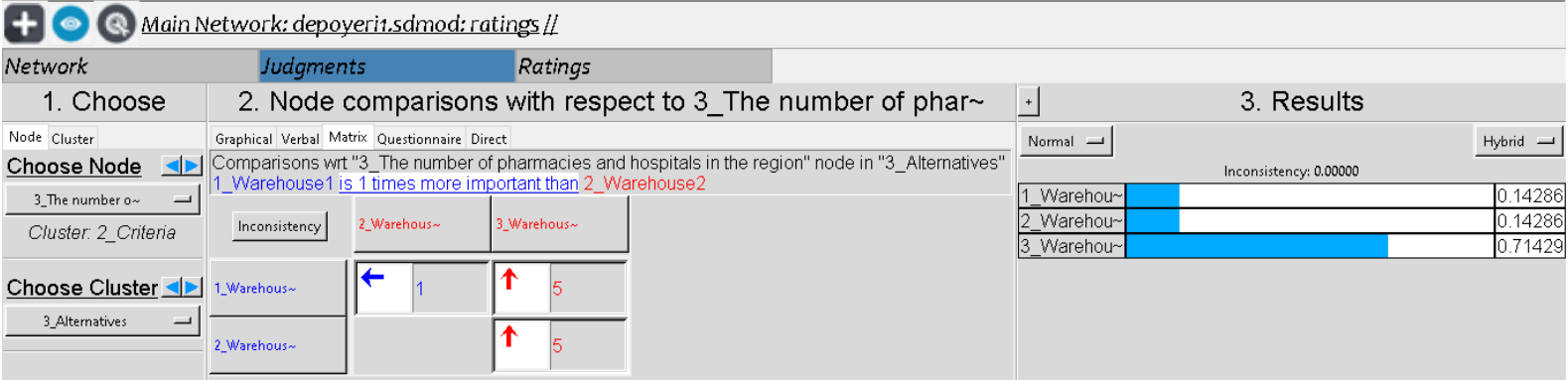

Figure 7. Program output based on the "The number of pharmacies and hospitals in the region" criterion

According to Figure 7, it is seen that the best alternative in terms of the number of pharmacies and hospitals in the region is Warehouse3, with a weight of 0.714 . The consistency rate for this assessment was calculated as 0.00 . The program output obtained as a result of the evaluation of alternative storage locations under the "Transportation conditions" criterion is given in Figure 8.

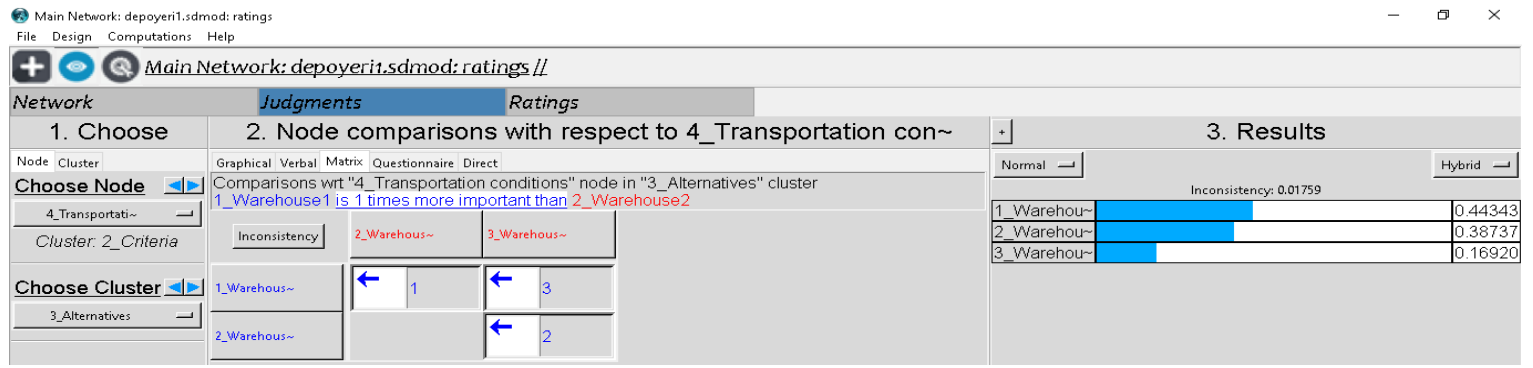

Figure 8. Program output based on the "Transportation conditions" criterion 
When the transportation conditions are taken into consideration in light of the information given in Figure 8, it is seen that the best alternative is Warehouse1 with a weight of 0.443 . The consistency rate for this assessment was calculated as 0.0175 . The program output obtained as a result of the evaluation of alternative storage locations according to the last criterion, "Infrastructure and physical conditions," is presented in Figure 9.

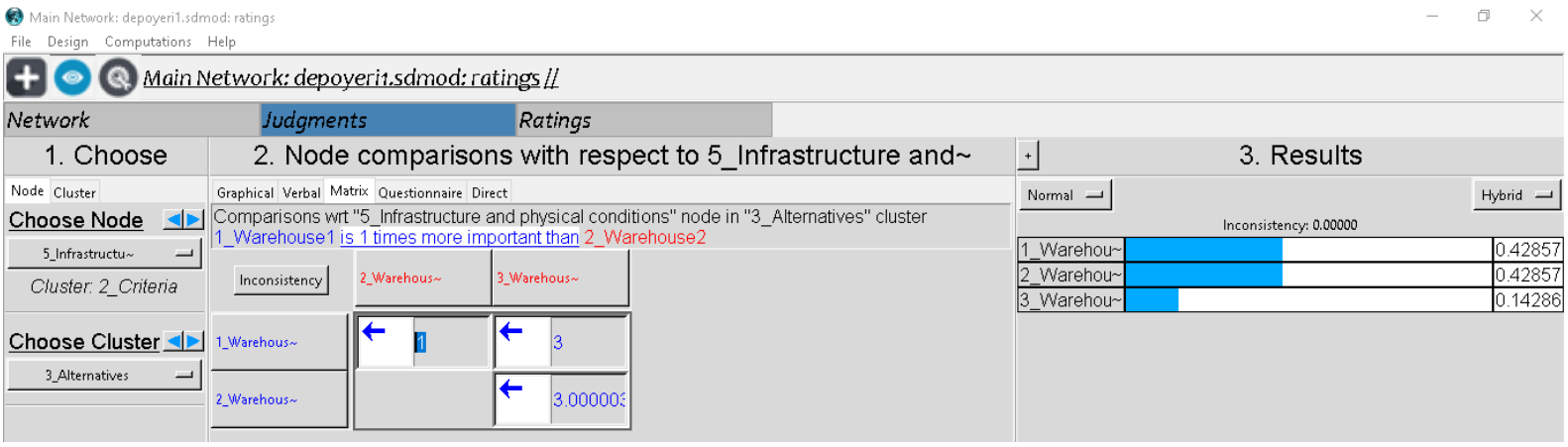

Figure 9. Program output obtained according to the "Infrastructure and physical conditions" criterion

Depending on the "Infrastructure and Physical Conditions" criterion, considering Figure 9, it is seen that Warehouse1 and Warehouse 2 have an equal weight of 0.429 . The consistency rate for this assessment was calculated as 0.00 .

Finally, all the criteria are handled together, and the findings obtained are presented in Figure 10 by prioritizing the alternate warehouse locations through eigenvectors calculated through the program.

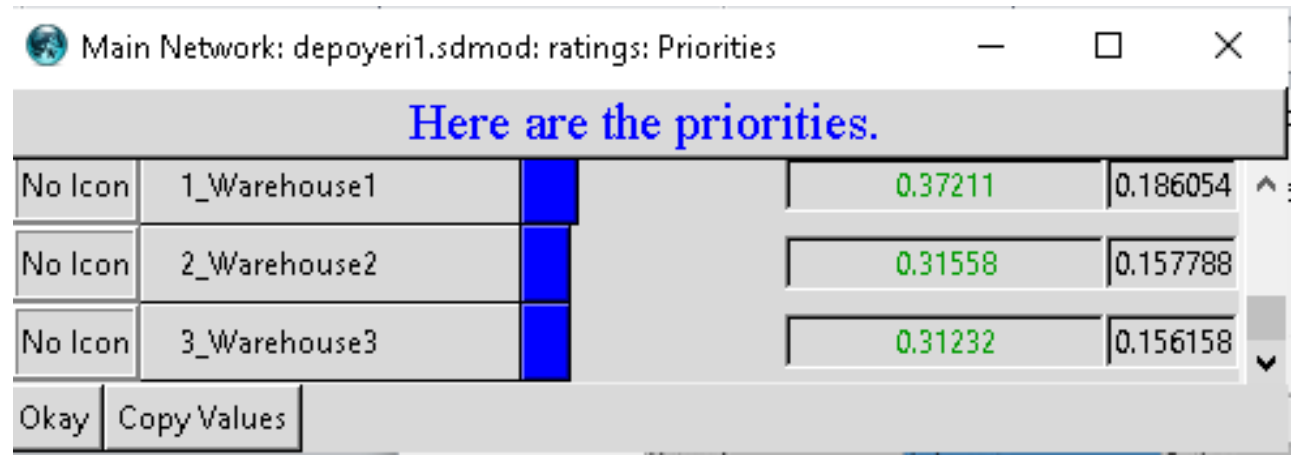

Figure 10. Priority values of alternative warehouse locations

Results presented in Figure 10 indicate that the most suitable place alternative for the pharmaceutical warehouse is Warehouse1 alternative, with a 0.372 weight. Besides, it has been demonstrated that the weight degrees of Warehouse 2 and Warehouse 3 are quite close to each other. Considering the alternatives, especially by taking the infrastructure and transportation conditions and the number of hospitals and pharmacies in the region into account, the result is not surprising. 
The results of this study can be a guideline for the managerial policy of pharmaceutical distribution channels. To the best of author's knowledge, this study is unique because it is the first of its kind in Turkey. The study provides a different lens on how to select the optimal location for a pharmaceutical warehouse. As future studies, it is planned to improve the hierarchical model for the pharmaceutical warehouse location selection model by increasing the number of criteria or creating sub-criteria and using more advanced multivariate decision-making techniques.

\section{REFERENCES}

1. Ergün, G.Ü.L., Tamer, E.R.E.N. (2017). Lojistik dağıtım ağ problemlerinde analitik hiyerarşi prosesi yöntemi ve hedef programlama ile depo seçimi. Harran Üniversitesi Mühendislik Dergisi, 2(1), 1-13.

2. Kolinski, A. (2016). Logistics Management - modern development trends, Chapter 4 Role of Warehouse Space in The Supply Chain (pp.147-164). Poznan: Poznan School of Logistics Press.

3. Singh, R.K, Chaudhary, N., Saxena, N. (2018). Selection of warehouse location for a global supply chain: A case study. Indian Institute of Management Bangalore, 30, 343-356.

4. Tengilimoğlu, D., Yiğit, V. (2017). Sağlık işletmelerinde tedarik zinciri ve malzeme yönetimi. 3. Baskı. Ankara; Nobel Akademik Yayınc1lık.

5. Erdin, C., Akbaş, H.E. (2019). A comparative analysis of fuzzy topsis and geographic information systems (gis) for the location selection of shopping malls: A case study from Turkey. Sustainability, 11(14), 3837.

6. Uysal, F., Tosun, Ö. (2012). Selection of Sustainable Warehouse Location in Supply Chain Using the Grey Approach. 3rd International Symposium on Sustainable Development, May 31 - June 01 2012, Sarajevo. 383-390.

7. Aktepe, A., Ersöz, S. (2014). AHP-VIKOR ve MOORA Yöntemlerinin Depo Yeri Seçim Probleminde Uygulanmas1. Endüstri Mühendisliği, 25(1), 2-15.

8. Cömert, S. E., Yener, F. (2017). Bir Gida Firmasi İçin Bulanik Analitik Hiyerarşi Prosesi İle Depo Yeri Seçimi. Uluslararası Íktisadi ve İdari Bilimler Dergisi, 2(2), 161-177.

9. Chen, C. (2009). A Decision Model of Field Depot Location Based on the Centrobaric Method and Analytic Hierarchy Process (AHP). International Journal of Business and Managament, 4, 71-75.

10. Karmaker, C.L., Saha, M. (2015). Optimization of warehouse location through fuzzy multicriteria decision making methods. Decision Science Letters, 4, 315-334.

11. Jaberidoost, M., Olfat, L., Hosseini, A., Kebriaeezadeh, A., Abdollahi, M., Alaeddini, M., Dinarvand, R. (2015). Pharmaceutical supply chain risk assessment in Iran using analytic hierarchy process (AHP) and simple additive weighting (SAW) methods. Journal of Pharmaceutical Policy and Practice, 8(1), 9. 
12. Velmurugan, R., Selvamuthukumar, S. (2012). The analytic network process for the pharmaceutical sector: Multi-criteria decision making to select the suitable method for the preparation of nanoparticles. DARU Journal of Pharmaceutical Sciences, 20(1), 59.

13. Bahmani, N., Blumberg, H. (1987). Consumer Preference and Reactive Adaptation to a Corporate Solution of the Over-The-Counter Medication Dilemma-An Analytic Hierarchy Process Analysis. Math. Modelling, 9(6), 293-298.

14. Elahi, F., Muqtadir, A., Anam, S., Mustafiz, K. (2017). Pharmaceutical Product Selection: Application of AHP. International Journal of Business and Management, 12(8),193-200.

15. Oey, E., Nitihardjo, E.C. (2016). Selecting Regional Postponement Centre Using PESTLEAHP-TOPSIS Methodology: A Case Study in a Pharmaceutical Company. Global Business Review, 17(5), 1250-1265.

16. Enyinda, E.A. (2010). A Model for Quantifying Strategic Supplier Selection: Evidence from a Generic Pharmaceutical Firm Supply Chain. International Journal of Business, Marketing and Decision Sciences. 3(2), 23-44.

17. Yıldırım, B.F. (2018). Çok kriterli karar verme yöntemlerine giriş. İçinde: E. Önder ve B.F. Yıldırım (Eds.), Sağlık yönetiminde karar verme-I, (s. 1-8). Bursa: Dora Yayıncılık.

18. Önder G., Önder E. (2018). Analitik Hiyerarşi süreci. İçinde: B.F. Yıldırım, E. Önder. (Eds.), Çok Kriterli Karar verme yöntemleri, (s. 21-64). Bursa: Dora Yayıncılık.

19. Saaty, T.L. (2000). Fundamentals of Decision Making ve Priority Theory with The Analytic Hierarchy Process. RWS Publications.

20. Kuruüzüm A., Atsan N. (2001). Analitik Hiyerarşi Yöntemi ve İşletmecilik Alanındaki Uygulamalar1. Akdeniz IIBF Dergisi, 1(1), 83-105.

21. Chandran B., Golden B., Wasil E. (2005). Linear Programming Models For Estimating Weights in The Analytic Hierarchy Process. Computers and Operations Research. 32(9), 2235-2254.

22. Ömürbek N., Şimşek A. (2014). Analitik Hiyerarşi Süreci ve Analitik Ağ Süreci Yöntemleri ile Online Alışveriş Site Seçimi. Yönetim ve Ekonomi Araştırmaları Dergisi, 12(22), 306-327.

23. Saaty, T.L. (1980). The Analytic Hierarchy Process, New York: McGraw-Hill.

24. T.C. Sağlık Bakanlığı İlaç ve Eczacılık Genel Müdürlüğü Geneşgesi Sayı: 48196. Tarih: 22 Ekim 1999. İlâçlar ve Ecza Deposunda Bulundurulan Ürünler İle İlgili İyi Dağıtım ve Muhafaza Uygulamaları Kılavuzu.

25. Fechner, I. (2009). Determinants of warehouse space market development in Poland. LogForum. 5(1), 3.

26. Kuo, R.J., Chi, S.C., Kao, S.S. (2002). A decision support system for selecting convenience store location through integration of fuzzy AHP and artificial neural network. Computers in industry. 47(2), 199-214. 